\title{
The Organizational and Economic Policy of the state Administration of Development of Railway Transport of Ukraine
}

\author{
Oleksandra Mandych ${ }^{1}$, Tetyana Suhorukova ${ }^{2}$, Olena Butenko ${ }^{3}$, Ivan Solomnikov ${ }^{2}$ and \\ Hanna Ostroverkh ${ }^{\left.2{ }^{*}\right]}$ \\ ${ }^{1}$ Kharkiv Petro Vasylenko National Technical University of Agriculture Educational and Scientific \\ Institute of Business and Management, Department of Economics and Marketing 61002, Kharkiv, \\ Alchevskikh st. 44, Ukraine \\ ${ }^{2}$ Ukrainian State University of Railway Transport, Department Economics and management of \\ industrial and commercial business, 61050, Kharkiv, Feierbakh Square 7, Ukraine \\ ${ }^{3}$ Kharkiv National University of Construction and Architecture, Department Management and Public \\ administration, 61002, Kharkiv, Sumska st. 40, m. Ukraine
}

\begin{abstract}
The article deals with the main directions of the organizational and economic policy of the state administration of the development of railway transport and provides suggestions for improving the management mechanism of the railway industry, to ensure the competitiveness of railway transport enterprises. Conceptual aspects of state administration of railway transport development are defined. Components of the organizational and economic policy of management development are provided. The necessity of reforming such components as an innovative renewal of production, overcoming structural deformations in industry, investment in the real sector is substantiated. the general mechanism of organizational and economic support of reform is provided.
\end{abstract}

\section{General problem statement}

Now in Ukraine, the governmental policy is aimed at minimizing government regulation where possible, focusing on the basic functions of the state, which includes the development and implementation of clear transport policy, monitoring implementation and evaluation of results. And it became a big problem for accurate functioning of railway transport.

The railway industry lost its competitiveness and is now inferior to road and air transport. State administration should make an effort to protect the interests of the country and society.

The main problems of the railway industry in Ukraine, that require state regulation of development, are as follows:

\footnotetext{
${ }^{1}$ Corresponding author: annakharkov8@gmail.com
} 
- the presence of territorial and structural imbalances in the development of transport infrastructure;

- insufficient accessibility of transport services for the population, mobility of labor resources;

- insufficient quality of transport services;

- low level of export of transport services, including the use of transit potential;

- insufficient level of transport security;

- strengthening the negative impact of transport on the environment, etc

\section{The analysis of recent researches and publications}

Development of the theory and methodology of state regulation of transport systems became the subject of many studies of contemporary domestic and foreign scientists in different scientific areas, including: V. L. Dykan, M. V. Korin, V. A. Ovchinnikova, A.V. Tolstova, G. D. Eitutis.

Organization of state administration and regulation in various spheres of society, engaged in such scientists: Yu. S. Barash, V. M. Gumaca, O. A. Degtyar, O. V. Daugaliou, O. M. Ivanitsky, A. M. Novikova, M. L. Pogrebetskiy, A. I. Semenchenko, O. V. Shkidchenko, etc [1-7].

According to their scientific achievements in this area, should be noted that the research related to the functioning and reform of railway transport remains particularly relevant, due to its strategic importance in the development of the state.

\section{Priorities of the organizational-economic policies state administration of development}

\subsection{Structural transformation and formation of the transport services market}

Today, the main task for Ukraine is to form a competitive transportation market and change the management principle of Ukrzaliznytsia JSC as a Joint Stock Corporation.

In the European Union, many railway transport enterprises are fighting for the customer with automobile transport. The share of rail transport in the EU is about $30 \%$. But in Ukraine, the share of freight by rail is about $60 \%$.

In 2018, the Ukrainian business transported about 320 million tons of cargo, of which about 107 million tons for export.

From this transport, Ukrzaliznytsia has got UAH 16.6 billion in operating income, due to what has financed capital investment and to cover the losses from passenger transportation.

The World Bank estimates that the restructuring of railway industries takes 5 to 10 years. The Association agreement of Ukraine with the EU provides for 8 years.

Since the entry into force of the Agreement, 4 years have passed, but the main railway legislation has not yet been adopted.

That is why, the restructuring of the railway system should be aimed at the gradual formation and development of a competitive market for transport services. This will be a prerequisite for achieving an optimal ratio of price and quality of cargo and passenger transportation, which will lead to a reduction in transport costs and prices.

Having achieved this goal, Ukraine will be able to implement the requirements of the EU directives regarding the commercial separation of the transport service from the state infrastructure. It should be taken into account that in order to ensure free competition between operators, two important aspects for the railway industry need to be addressed - 
different gauge between the Ukrainian and European network $(1520 \mathrm{~mm}$ and $1435 \mathrm{~mm}$, respectively) and high barriers to entry into the business of rail transport.

In Ukraine, the railway network primarily serves large volumes of demand in the mining and metallurgical industry both in the domestic and foreign markets.

In passenger transportation, railways had to compete with the growing share of air and road transport, but in recent years Ukrzaliznytsia JSC has not tried to improve services for passenger transportation, so the railway industry has lost a large share of passenger transportation.

To renew the environmental, economic and social benefits of rail transport and increase its transit potential, Railways will have to provide a quality level of service.

This can be achieved only through the creation of a new organizational and economic policy of state development management, which would include: the improvement of rolling stock, infrastructure, technology, and management.

\subsection{Railway reform should include the following steps:}

- making changes and additions necessary for structural changes in the current legislation of Ukraine: "On Railway Transport", "On Natural Monopolies", "On Objects of State Ownership that are not subject to Privatization", as well as the Charter of the Railways of Ukraine: Ukraine;

- development and adoption of the State target program of railway transport reform in

- separation of activities not directly related to road traffic, which will, in particular, reduce the financial burden on the cost of freight and transport element in the cost of production;

- implementation of the financial and economic model that will ensure clear and transparent accounting and distribution of financial flows by type of activity;

- phase-out of cross-subsidization of passenger transport with freight income;

- creation of favorable conditions for attraction of investments necessary for updating and modernization of technical and production base of Railways, if necessary, making appropriate changes and additions to the national legislation and industry regulations;

- improvement of the regulatory framework, which should establish uniform requirements and conditions for access to the infrastructure for any traffic operators with the simultaneous introduction of certification and licensing system to provide quality and safe services.

- improvement of the tariff policy on freight transport in accordance with the WTO requirements with the consolidation of the state regulatory functions on tariffs for socially important passenger transport and the introduction of effective compensation for unprofitable suburban, privileged and other modes of transport.

Today, the railway is in fierce competition with road and air transport. In order to achieve the goal of greater rail traffic, States and the business community must become more active.

First of all, it is necessary to create the correct organizational and economic policy of the state administration of development where the main goal will be the interaction of policy and the railway industry, which will further increase the attractiveness of railway transport in Ukraine. The choice of policy measures should be the subject of a financial reserve for further development [8].

The spheres of state administration in the railway industry should influence:

- infrastructure management;

- coordination between different types of transport infrastructure, including transport exchange points and logistics centers; 
- implementation of agreed licensing and certification mechanisms for products and transport services;

- implementation of the agreed tariff and tax policy;

- management of Supervisory activities in the transport sector;

- cooperation with Central and local Executive authorities in the development of the transport sector;

- ensuring the harmonization of social standards of transport services for all population groups and regions of the country;

- implementation of harmonization of environmental standards and ensure their compliance [8].

The main principles of the organizational and economic policy of the state administration of the development of railway transport should be the following:

- development and technical improvement of transport infrastructure;

- providing a legal basis for transport activities and its supervision;

- structural reforms and institutional changes in transport;

- tariff policy for monopoly services;

- technical and environmental safety;

- ensuring state transport security;

- social and labor legislation, which should be clear and unique in the transport sector [8].

For the implementation of these processes of influence, organizational and economic policy, which will be based on the tools, makes it possible to make different decisions depending on specific tasks and situations.

It is important to emphasize that the list of specific instruments of influence is changing due to changes in external and internal factors, the emergence of new instruments, the improvement of the main elements of the regional management system (governance, structures, resources, technologies), which is an objective process of renewal.

\section{Organizational and economic mechanism of state administration of railway transport development}

The main objectives of the state policy mechanism should include improving the efficiency of rail transport, reduce costs and improve the quality of services.

To achieve these goals, it is necessary to act in two main directions: reforming the existing system of railway tariffs supporting competition in railway transport.

At the initial stage, it is proposed to separate the management of infrastructure and rail transport to create an incentive for new operators owning rolling stock to use the infrastructure of Ukrzaliznytsya JSC. And act as the leading operator of freight transport; while passenger transport is allocated to separate subsidiaries, which may eventually become the property of subjects of the state, local governments or may even be privatized.

In addition, the management mechanism should fully allow for competition between vertically integrated railway companies.

The main components of the mechanism of state administration of railway transport development:

- regardless of how the railway system was structured during the reform period, it is first necessary to establish an organizational and economic policy of state regulation - to ensure the development of competition (which is especially important given the high proportion of Railways compared to other modes of transport), and partly to ensure overall efficiency; 
- regulation is needed in areas such as the structure of competition (especially nondiscriminatory and competitive access to infrastructure) and freight tariffs in those segments where market mechanisms are in place (direct trade-offs against the nature of competition).

The relevant regulatory framework depends on the chosen structure of the railway industry and, in particular, on the relationship between the infrastructure management organization and the freight carriers.

Until now, the issue of access to infrastructure is regulated by the Cabinet of Ministers of Ukraine (wherever it is), and tariffs for freight transportation are regulated by the Ministry of the infrastructure of Ukraine. However, this regulatory framework may change with the new policy structure.

\section{Conclusion}

The ultimate goal of the organizational and economic state policy for the development of railway transport in Ukraine should be the formation of a privatized sector of rail transport, works on a commercial basis and is composed of many separate and competing enterprises that must use the state support infrastructure.

At the first phase e of the reform, which has already formally ended with the creation of Ukrzaliznytsya JSC, provided for the separation of functions of state regulation and economic activity through the creation of a quasi-independent operator company, which has in its composition separate interrelated activities.

In the second phase of the reform, these activities will be separated legally and institutionally, placed in an open competitive environment and, where possible, transferred to private sector.

In the third phase, incentives will be created to promote competition and, if possible, the privatization of all types of transportation.

\section{References}

1 V. L. Dykanj M. V. Korin Bulletin of the Economy of Transport and Industry, 61. 9-19, (2018).

2 V.L. Dykanj, O.Gh. Kirdina Bulletin of the Economy of Transport and Industry, 28, 1320, (2009).

3 V.L. Dykan, M.V. Kondratyuk Bulletin of the Economy of Transport and Industry, 26, 13-18, (2009).

4 V.L. Dykan, G.E. Ostroverkh. Bulletin of the Economy of Transport and Industry, 62, 11-19, (2018).

5 V.O. Ovchynnikova, Stratehichne upravlinnya rozvytkom zaliznychnoho transportu Ukrayiny, Kharkiv, 427 (2017)

6 A.V. Tolstova Bulletin of the Economy of Transport and Industry, 40, 303-306, (2012).

7 National Transport Strategy of Ukraine 2030 URL: https://mtu.gov.ua/files/for_investors/230118/National\%20Transport $\% 20$ Strategy $\% 20$ of \%20Ukraine.pdf].

8 V. Yanovska, Socio-economic effects of high-speed highway project "China-UkraineEU", Materials of the Round table of Association High-Speed Highways, 12 (2018).

9 V.N. Goncharov, E.V. Ivanova, Concept of strategic organization of innovative activity of enterprises, URL: www.maop.vorstu.ru/Gancharov.html. Accessed 07 May 2019. 
10 Intelligent Information Systems in Management, https://rep.bntu.by/bitstream/handle/data/23986/\%D0\%A2..B8.pdf? sequence=11. (2019).

11 E.O. Naumenko On the model of management of the innovative process of the enterprise in modern conditions, URL: http://ej.kubagro.ru/2006/04/pdf/03.pdf. Accessed 03 May 2019 .

12 V.O. Zadoya, Problems of transport Economics, 9, 71-76 (2015). 